\title{
A new species of centipede of the genus Cryptops Leach (Scolopendromorpha: Cryptopidae) from southern Western Ghats with a key to the species of Cryptops in India
}

\author{
Dhanya Balan ${ }^{1}$, P.M. Sureshan ${ }^{2} \&$ Vinod Khanna ${ }^{3}$ \\ 1,2 Western Ghat Regional Centre, Zoological Survey of India, Calicut, Kerala 673006, India \\ ${ }^{3}$ SaiDrishti, 151, AshokVihar, Salawala,Dehra Dun, Uttarakhand 248001, India \\ Email: ${ }^{1}$ dhanyamkrishna@gmail.com (corresponding author), ${ }^{2}$ pmsuresh43@yahoo.com, ${ }^{3}$ drvkhanna51@gmail.com
}

\begin{abstract}
A new species of blind cryptopid centipede of the genus Cryptops Leach belonging to the hortensis group viz. Cryptops (C.) malabarensis is described from the southern Western Ghats, Kerala, India and the family Cryptopidae (Scolopendromorpha) is reported for the first time from the area. Affinities of the new species with a Madagascar species are discussed and a key to separate the Indian species of Cryptops is also provided.
\end{abstract}

Keywords: Chilopoda, Cryptopidae, Cryptops malabarensis sp. nov, key, new species, Scolopendromorpha, southern Western Ghats.

Date of publication (online): 26 April 2012

Date of publication (print): 26 April 2012

ISSN 0974-7907 (online) | 0974-7893 (print)

Editor: Gregory D. Edgecombe

Manuscript details:

Ms \# 03035

Received 14 December 2011

Final received 06 February 2012

Finally accepted 30 March 2012

Citation: Balan, D., P.M. Sureshan \& V. Khanna (2012). A new species of centipede of the genus Cryptops Leach (Scolopendromorpha: Cryptopidae) from southern Western Ghats with a key to the species of Cryptops in India. Journal of Threatened Taxa 4(4): 2510-2514.

Copyright: (C) Dhanya Balan, P.M. Sureshan \& Vinod Khanna 2012. Creative Commons Attribution 3.0 Unported License. JoTT allows unrestricted use of this article in any medium for non-profit purposes, reproduction and distribution by providing adequate credit to the authors and the source of publication.

Acknowledgement: We are grateful to Dr. K. Venkataraman, Director, Zoological Survey of India, Kolkata and C. Radhakrishnan, Officer-inCharge, Western Ghat Regional Centre, Zoological Survey of India, Calicut for providing facilities and encouragement. DB is grateful to Ministry of Environment and Forests, Govt. of India for awarding the Junior Research Fellowship and to Dr. John Lewis, UK, for the timely help and advice on matters of taxonomy, assistance with the literature and for useful comments on the manuscript. DB is also thankful to Dr. S. Shankar, Senior Scientist, Kerala Forest Research Institute, Peechi, Kerala for guidance on matters concerned with the studies in soil ecology. We are grateful to PCCF, Kerala Forest and Wildlife Department for the study permission and Staff, Malabar Wildlife Sanctuary for their encouragement and support during the study. Thanks are also due to Mr. P.K. Umesh, Mr. K.C. Harish and Mr. R.A. Aswanth for assistance rendered during the field trips.
The Western Ghats in India, with its very diverse assemblage of flora and fauna is one of the hotspots of biodiversity (Myers et al. 2000). With a few exceptions, the invertebrate fauna of the Western Ghats has been inadequately studied both in terms of their diversity and conservation priorities (Kunte in press). Though an integral part of the soil ecosystems, the fauna of scolopendromorph centipedes (Chilopoda: Scolopendromorpha) of the Western Ghats is still little known except for the pioneering works by Attems (1930), Jangi \& Dass (1984), Yadav (1993) and Sureshan et al. (2006). A perusal of the literature reveals the occurrence of 40 species of scolopendrid centipedes belonging to eight genera and two families in the Western Ghats. Like the families Plutoniumidae and Scolopocryptopidae and the orderGeophilomorpha, the family Cryptopidae are blind centipedes, lacking ocelli. Cryptops Leach, 1815, is the largest genus of the family Cryptopidae, with 153 named species worldwide (Lewis 2002), in four subgenera i.e., C. (Cryptops) Leach, 1815; C. (Chromatonops) Verhoeff, 1906; C. (Haplocryptops) Verhoeff, 1934 and C. (Trigonocryptops) Verhoeff, 1906 (Bonato et al. 2011). The smaller size and fragile body, coupled with an abundance of species names, often founded on inadequate samples and with imprecise descriptions, make cryptopid centipedes a taxonomically difficult group and only seven species in two genera have so far been described from India. The Indian species of Cryptops are Cryptops (C.) feae Pocock, 1891, Cryptops (C.) doriae Pocock, 1891, Cryptops (C.) kempi Silvestri, 1924, Cryptops (C.) setosior Chamberlin, 1959 and Cryptops (Trigonocryptops) orientalis Jangi, 1955 (Khanna 2005, 2008). 


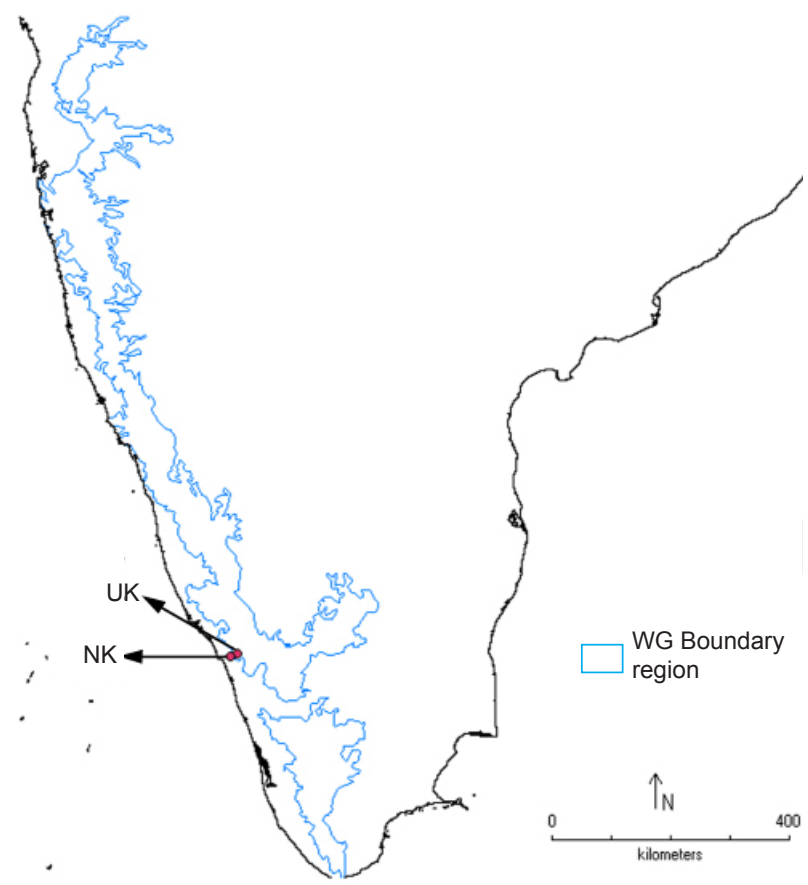

Figure 1. Location of the Western Ghats in southern India with the two localities of Cryptops malabarensis sp.nov. indicated by coloured circles.

UK - Urakkuzhy, Malabar Wildlife Sanctuary; NK - Narayankualam.

\section{Materials and Methods}

During the faunal exploration surveys, interesting specimens of cryptopids were collected from the forested tracts of southern Western Ghats and its foot-hills (Fig. 1). The collections represent the first record of the family Cryptopidae from the area and permit the description of a new species of Cryptops. The new species shows very close affinity with $C$. decoratus Lawrence, 1960, which has its distribution in Madagascar (holotype), Mauritius (Lewis 2002), and the Seychelles (Lewis 2007). The specimens are deposited in the Zoological Survey of India, Western Ghat Regional Centre, Calicut (ZSIC), Kerala, India.

Digital imaging was carried out using a Leica M205A stereomicroscope and a Leica DFC-500 digital camera. Scanning electron micrographs were captured with a Jeol JCM-5000 Neoscope bench-top SEM. The terminology used by Bonato et al. (2010) is followed in this paper.

\section{Cryptops (Cryptops) malabarensis sp. nov.} (Figs. 2-3 and Images 1-5)

\section{Material examined}

Holotype: 01.viii.2011, 11032'40.59'N \& 75055'33.40'E, elevation 641.2m, Urakkuzhy, Kakkayam, Malabar Wildlife Sanctuary, Kerala, India, coll. Dhanya Balan, (ZSI/WGRC/I-R/INV 2111) (Images 1-5).

Paratypes: 29.viii.2011, three specimens, from type locality, coll. Dhanya Balan (ZSI/WGRC/I-R/ INV 2080, 2108, 2109); 01.iv.2011 two specimens, 11030'26.98'N \& 75048'24'"E, elevation 145m, Narayamkulam, Calicut District, Kerala, India, coll. P.K. Umesh (ZSI/WGRC/I-R/INV 2079).

Diagnosis: A species of Cryptops lacking anterior transverse suture on Tergite-1; tergite paramedian sutures from tergite 4 or 5-20; absence of saw teeth on the ultimate femur (C. hortensis group); ultimate leg tibia with 4-7 saw teeth on the tibia and 3-4 on tarsus one; no accessory spurs associated with the tarsal claw.

\section{Description of holotype}

Body length 23mm. Colour (before and after preservation) greyish-brown with dark subcutaneous pigment on tergites. Ultimate legs yellow.

Antennae composed of 17 articles; basal two articles relatively stout with long setae distally. An irregular whorl of long setae on the proximal end of articles $1-3$, the rest with setae scattered irregularly, not in whorls but the dorsal middle region is not densely covered. Short, fine setae abundant from $6^{\text {th }}$

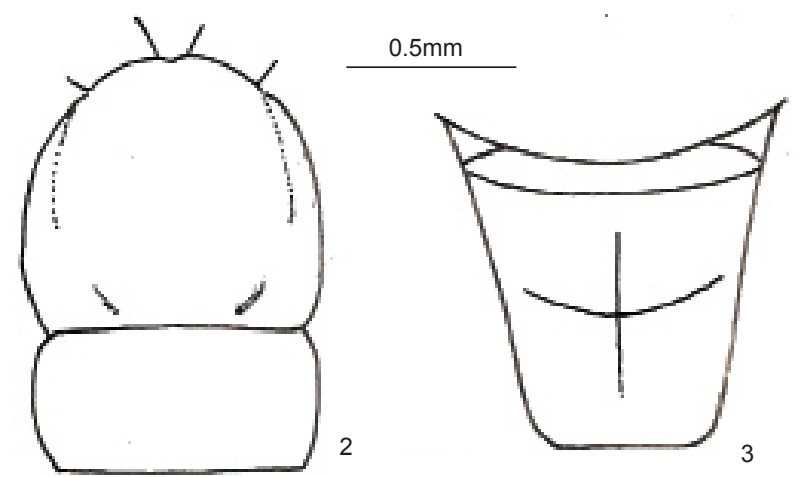

Figures 2-3. Cryptops (Cryptops) malabarensis sp. nov. (ZSI/WGRC/I-R/INV 2108)

2 - Cephalic plate and Tergite-1; 3 - Sternite suture 

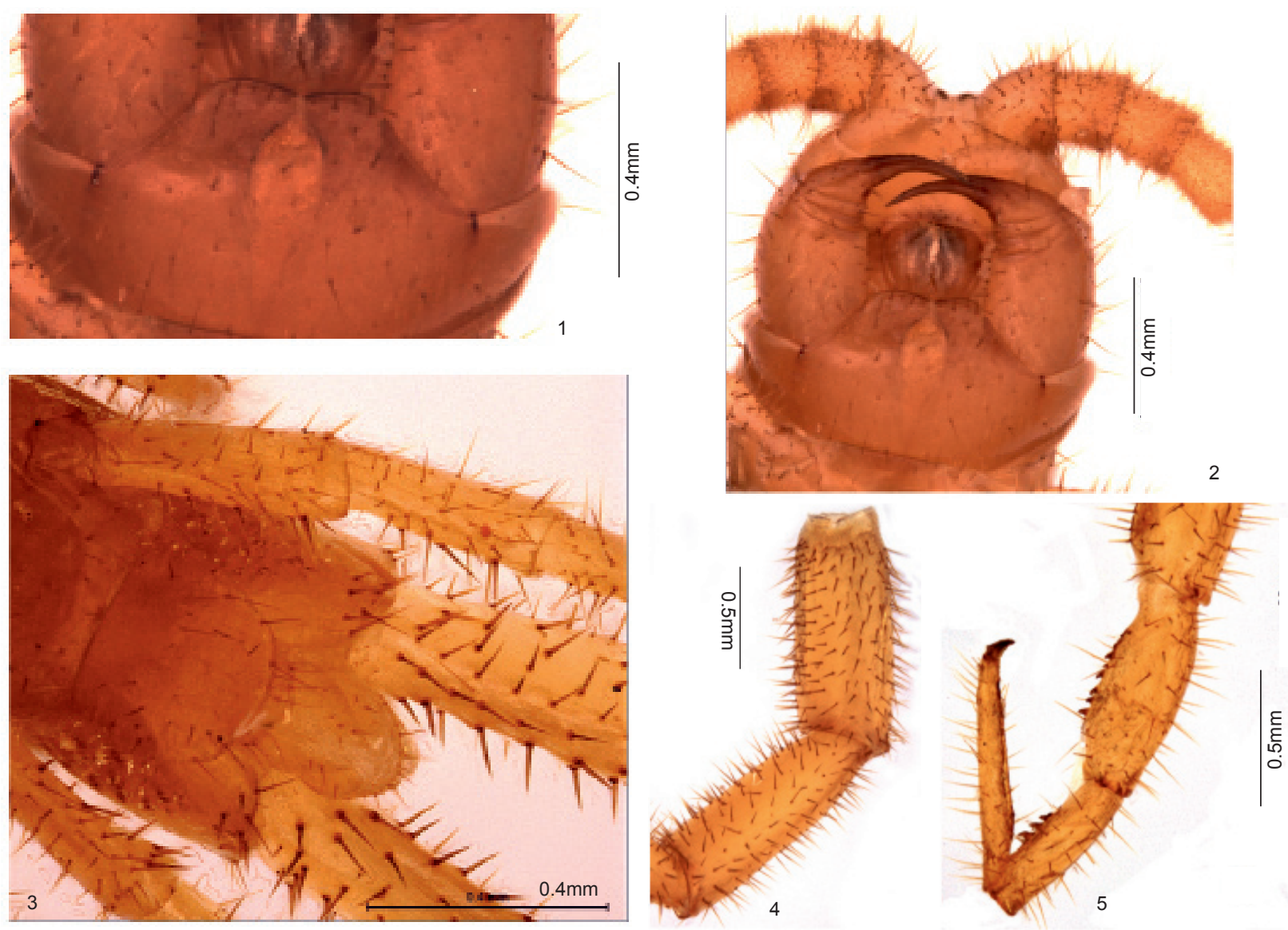

Images 1-5. Cryptops (Cryptops) malabarensis sp. nov. (ZSI/WGRC/I-R/INV 2109). (C) WGRC, ZSI, Calicut 1 - Forcipular coxosternum; 2 - Cephalic plate ventral; Sternite-21; Prefemur and femur; Tarsus and tibia

article onwards (Images $4 \& 5$ ).

Cephalic plate and tergite one without sutures, tergite one overlying the posterior edge of the cephalic plate (Fig. 2). Anterior edge of forcipular coxosternite weakly bilobed (Image 1) and with four long and one small setae on each side. Tergite paramedian sutures from tergite 4 or 5-20. Tergite 21 without sutures and with slightly angular posterior margin. Sternites with longitudinal and transverse sulci, longitudinal sulci longer than the transverse (Fig. 3). Sternite 21 with sides converging very slightly and straight posterior margin (Images $2 \&$ 8). Legs 1-19 with undivided tarsi. No accessory spurs associated with the tarsal claw (Image 9).

Coxopleuron with nine large pores and with at least three minute setae in porefield; three or four fine setae on posterior margin and upto five between this and porefield. Posterior area of coxopleuron is poreless.

Leg 20 with dense fine setae ventrally on prefemur, femur and tibia in all specimens. Ultimate legs with strong setae on anterior, ventral and posterior surfaces of prefemur and on ventral and posterior surfaces of femur. Median longitudinal glabrous area absent. No distal tubercle on tibia and tarsus. No saw tooth on the femur (Image 4); seven on the tibia and three on the tarsus 1 (Image 3).

\section{Additional information from paratypes}

Body length of paratypes varies between 11-21 $\mathrm{mm}$. Antennae of leftside is damaged in 2079. When compared to the holotype, the number of saw teeth on the ultimate leg tibia varies from four (2079), five $(2080)$ or six $(2108,2109)$ and on tarsus 1 the variation is either three $(2080,2108,2109)$ or four $(2079)$ saw teeth. The number of coxopleural pores are not clearly countable.

\section{Etymology}

The species is named after the type locality "Malabar Wildlife Sanctuary”, Kerala, India. 

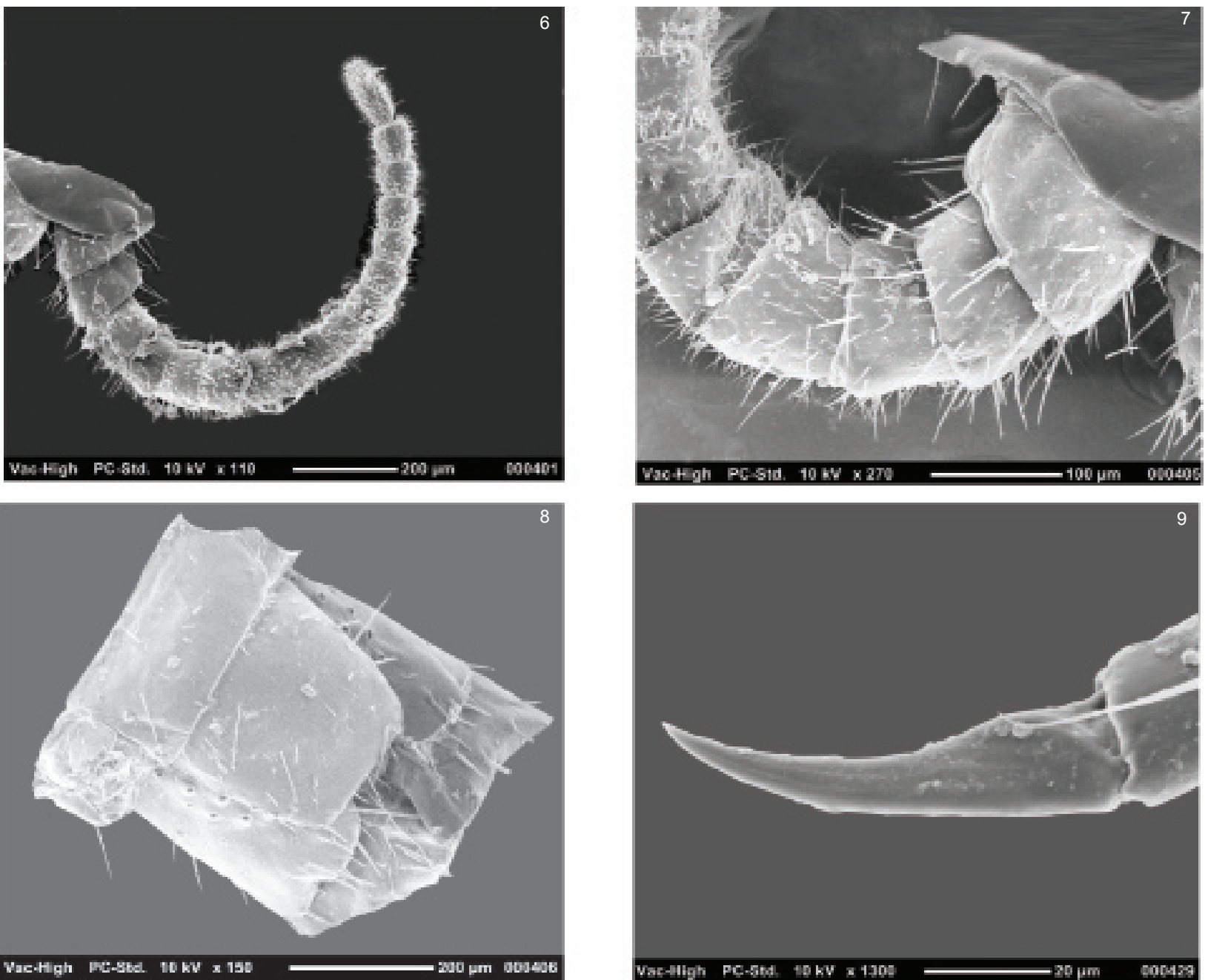

Images 6-9. Cryptops (Cryptops) malabarensis sp. nov. (ZSI/WGRC/I-R/INV 2080). @) WGRC, ZSI, Calicut 6 - Dorsal view of antenna; 7 - Basal antennal articles; Sternite-21; Pretarsus of leg from middle trunk

Table 1. Ecological observations from the sampling sites

\begin{tabular}{|l|c|c|}
\hline $\begin{array}{l}\text { Physiographic } \\
\text { category }\end{array}$ & Midland & Highland \\
\hline Sampling sites & Narayamkulam & Kakkayam \\
\hline Altitude & $145 \mathrm{~m}$ & $641 \mathrm{~m}$ \\
\hline Atm. temp & $24-30^{\circ} \mathrm{C}$ & $19-28^{\circ} \mathrm{C}$ \\
\hline $\begin{array}{l}\text { Distance from } \\
\text { water source }\end{array}$ & $120 \mathrm{~m}$ & $75 \mathrm{~m}$ \\
\hline Type of vegetation & $\begin{array}{c}\text { agro ecosystem } \\
\text { near a semi } \\
\text { deciduous forest } \\
\text { patch }\end{array}$ & $\begin{array}{c}\text { moist deciduous } \\
\text { forest }\end{array}$ \\
\hline Soil temperature & $23-27^{\circ} \mathrm{C}$ & $15-25^{\circ} \mathrm{C}$ \\
\hline soil pH & 4.91 & 4.76 \\
\hline Org. Carbon & 3.12 & 9.15 \\
\hline
\end{tabular}

\section{Ecological observations}

Habitat: The specimens were collected from moist deciduous forest tracts of southern Western Ghats. All specimens were found in loose soil, about $4-5 \mathrm{~cm}$ below the surface. Ecological parameters of the two collection localities during the period of March-April 2011 are provided in Table 1.

\section{Discussion}

Cryptops malabarensis sp. nov. is conspicuously different from the other described Indian species of Cryptops included in the $C$. doriae group (having saw teeth on the ultimate leg femur); and falls in the Old World C. hortensis group of Lewis (2011) (those lacking saw teeth on the ultimate leg femur), which have not yet been reported from India. C. malabarensis sp. nov. closely resembles $C$. decoratus Lawrence (1960), which is also 
1. Sternites, at least on some anterior segments with trigonal sutures

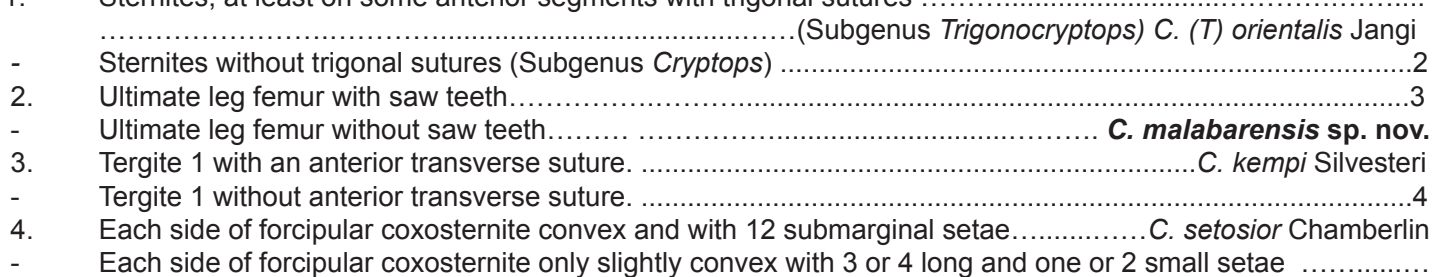

Each side of forcipular coxosternite only slightly convex with 3 or 4 long and one or 2 small setae .............

a member of the Old World $C$. hortensis group. The two species share the absence of sutures on the cephalic plate and tergite one; anterior margin of coxosternite almost straight, an overlapping number of coxopleural pores (7-9), a similar number of setae in the porefield (at least three) and ultimate leg characters such as prefemur with long fine setae dorsally, absence of a median longitudinal glabrous area, tibia with four and tarsus 1 with two saw teeth. However the new species differs from the holotype description of $C$. decoratus, in having no median ridges on the tergites, no posterior median depression on tergite 21 and the absence of accessory spurs on the pretarsi. C. decoratus is a Malagasy species closely related to $C$. melanotypus Chamberlin, 1941 from the Philippines, Mauritius and the Seychelles but Lewis (2011) was unsure of their exact status. However, the strong similarity between the new species and $C$. decoratus and C. melanotypus suggests dispersal of a group of closely allied species over a wide area.

\section{REFERENCES}

Attems, C. (1930). Myriopoda. 2. Scolopendromorpha. Das Tierreich. De Gruyter, Berlin 54: 1-308.

Bonato, L., G. Edgecombe, J.G.E. Lewis, A. Minelli, L.A. Pereira, R.M. Shelley \& M. Zapparoli (2010). A common terminology for the external anatomy of centipede (Chilopoda). Zookeys 69: $17-51$.

Bonato, L., G.D. Edgecombe \& M. Zapparoli (2011). Chilopoda Taxonomic overview, pp. 363-443. In: Minelli, A. (ed.). Treatise on Zoology - The Myriapoda -Vol. 1. Brill, Leiden, 530pp.

Chamberlin, R.V.(1959). EntomologischeErgebnisse der Deutschen Indien-Expedition 1955-1958. On some chilopods from India. Entomologische Mitteilungen 19: 21-24.

Jangi, B.S. (1955). The chilopod fauna (Scolopendromorpha) of Nagpur India. Annals and Magazines of Natural History 12.7: 69-80.

Jangi, B.S. \& C.M.S. Dass (1984). Scolopendridae of the Deccan. Journal of Scientific and Industrial Research 43(1): 27-54.

Khanna, V. (2005). Trends in the distribution of centipedes from India. Annals of Forestry 13(1): 130-140.
Khanna, V. (2008). National register of the valid species of Scolopendrid centipedes (Chilopoda: Scolopendromorpha) in India. Biosystematica 1(2): 33-45.

Kunte, K. (2011 in press). Biogeographic origins and habitat use of the butterflies of the Western Ghats, south-western India. In: Priyadarshan, D.R., K.A. Subramanian, M.S. Devy \& N.A. Aravind (eds.). Invertebrates in the Western Ghats - Diversity and Conservation. Ashoka Trust for Research in Ecology and the Environment, Bengaluru.

Lawrence, R. (1960). Faune de Madagascar 12. Myriapodes Chilopodes 76-84.

Leach, W.E. (1815). A tabular view of the external characters of four classes of animals which Linné arranged under Insecta, with the distribution of the genera composing three of these classes into orders etc., and descriptions of several new genera and species. Transactions of the Linnaean Society of London (Series 1) 11: 306-400.

Lewis, J.G.E. (2002). The scolopendromorph centipedes of Mauritius and Rodrigues and their adjacent islets (Chilopoda: Scolopendromorpha). Journal of Natural History 36: 96.

Lewis, J.G.E. (2007). Scolopendromorph centipedes from Seychelles with a review of previous records (Chilopoda: Scolopendromorpha). Phelsuma 15: 8-25.

Lewis, J.G.E. (2011). A review of the species in the genus Cryptops Leach, 1815 from the Old World related to Cryptops (Cryptops) hortensis (Donovan, 1910) (Chilopoda, Scolopendromorpha). International Journal of Myriapodology 4: 11-50.

Myers, N., R.A. Mittermeier, C.G. Mittermeier, G.A.B. da Fonseca \& J.Kent (2000). Biodiversity hotspots for conservation priorities. Nature 403: 853-858.

Pocock, R.I. (1891). On the Myriopoda of Burma. Part 2. Report upon the Chilopoda collected by Sig. L. Fea and Mr. E.W. Oates. Annali del Museo Civico di Storia Naturale di Genova (Series 2)10: 401-432.

Silvestri, F. (1924). Myriapoda from the Siju Cave, Garo Hills, Assam. Record of the Indian Museum 26: 71-79.

Sureshan, P.M., V. Khanna \& C. Radhakrishnan (2006). Additional distributional records of scolopendrid centipedes (Chilopoda: Scolopendromorpha) from Kerala. Zoos' Print Journal 21(6): 2285-2291.

Yadav, B.E. (1993). Scolopendridae (Chilopoda) of Western Ghat with some first records from the state of Maharashtra, India. Records of Zoological Survey of India 93(3-4): 321-328. 